\title{
THE ROLE OF BIOFUELS IN FOOD COMMODITY PRICES VOLATILITY AND LAND USE
}

\author{
- Oláh Judit, Lengyel Péter, Balogh Péter, Harangi-Rákos Mónika, Popp \\ József
}

\begin{abstract}
The goal of this study is to investigate the cause of a growing food price volatility. We analyse whether food price volatility is mainly induced by transfer of the oil price shock or if it is the consequence of a rising and competitive biofuel production. Furthermore, we evaluate the impact of biofuels on land use as well. Food prices have lately surged and declined sharply and become more volatile. High fuel prices combined with a rising biofuel production created a link between crude oil and food prices. We investigated the impact of a biofuel production on an increased volatility in oil and food prices, and found correlations between cereals, sugar and vegetable oil price index and crude oil prices from 2003 to 2016. Our results show that the main driver for food price fluctuation is mainly the oil price shock. The increasing biofuel output has been associated with a rising protein-rich animal feed production. The use of co-products as animal feed has land use implications including GHG emission savings because co-products reduce land and the demand for chemical inputs required in the feed production.
\end{abstract}

Keywords: bioenergy, biofuels, price transmission, co-products, land use JEL Classification: Q41, Q42, Q43

\section{INTRODUCTION}

An increased biofuel production has generated the "food versus fuel debate". In parallel with the rising output of ethanol and biodiesel, the demand for feedstock, mainly for cereals, sugar cane and vegetable oils has increased as well. The question arises whether an increasing biofuel consumption has played a role in rising food prices and land use changes. The main aim of our research is to investigate whether the link between oil and food prices is substantial and constant over time. In addition, the contribution of the biofuel industry to the land use for cultivation of feedstocks is also analysed.

The energy consumption is still increasing, with an approximate $570 \mathrm{EJ}$ consumed at the primary energy level in 2014. Out of this total, 78.3\% was provided by fossil fuels, $2.5 \%$ from nuclear, $8-9$ by biomass mainly from wood combustion, $3.9 \%$ from hydro, and $6.4 \%$ from other renewable energy sources. Bioenergy amounted to $8.9 \%$ of global final energy consumption with 76 exajoules (EJ). In the last three and a half decades, the energy supplies worldwide have increased almost twice but the relative share of renewables has grown from 13\% to 19\%, including $8.9 \%$ of traditional biomass and $10.3 \%$ of modern renewables (Fig. 1). The "traditional" share of bioenergy has been relatively stable for many years, while the "modern" share has grown since the late 1990s. 
Out of the 76 EJ of bioenergy produced globally in 2013, modern renewables accounted for 41EJ and traditional biomass amounted to $35 \mathrm{EJ}$ (IEA, 2016). The current trends in developing countries are projected to continue with the use of a higher share of more modern forms of biomass in the energy supply. Technological progress contributed to the increasing use of renewable energy in the rural heating and cooking sectors (Popp, Lakner, Harangi-Rákos, \& Fári, 2014).

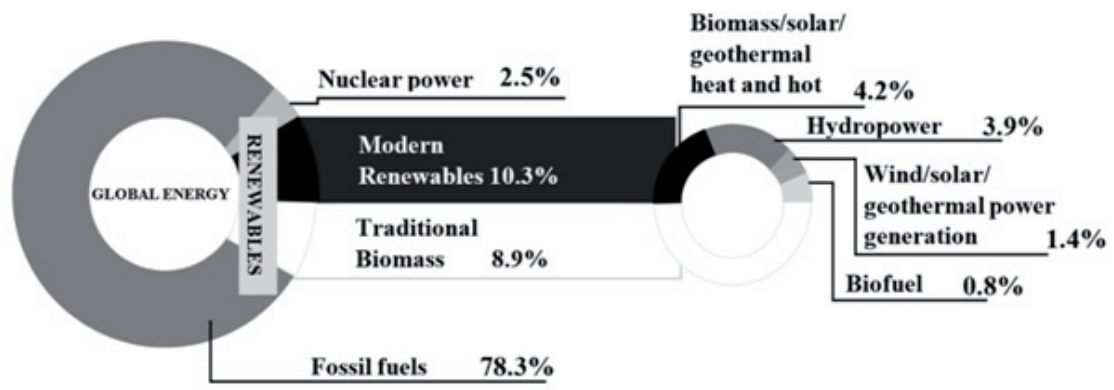

Fig. 1 - The contribution from renewables to the global final energy consumption in 2014. Source: IEA (2016)

The share of "modern" renewables (not including traditional biomass) is still insignificant in the total renewable energy production worldwide, however, their use is steadily increasing. Biofuels used in transportation has spurred the development of bioenergy (Popp et al., 2014). The transport sector has a share of about $28 \%$ in the global final energy consumption (OECD/FAO, 2017). Transport biofuels constitute some $3 \%-4 \%$ of total road transport fuel and about $7 \%$ (3.5 EJ/year) of total bioenergy use today. Cuts in production costs will be crucial to make the next generation biofuels competitive. At the same time, a strong competition from other renewables (wind and solar) can be expected (Popp et al., 2014).

\subsection{Transport biofuel: food versus fuel debate}

Currently, the share of ethanol in the global output of liquid biofuels is about $75 \%$. In 2014 2016, the production of fuel ethanol achieved 96 billion litres on average and the world biodiesel output was 34 billion litres (Fig. 2 and 3). The top two fuel ethanol producers, the U.S. and Brazil, realized $82 \%$ of a global output. The global fuel ethanol output is expected to expand modestly from 96 billion litres in 2014-2016 on average to 113 billion litres by 2026 . Most of the extra ethanol output is projected to be produced in Brazil, the U.S. and Thailand (OECD/FAO, 2017).

The fuel ethanol production in the U.S. is forecasted to go up from 52.6 billion litres in 20142016 on average to 58 billion litres by 2026 (OECD/FAO, 2017a). The advanced and the cellulosic mandates was waived by Environmental Protection Agency (EPA) in 2017 based on the absence of production capacity for cellulosic ethanol (EPA, 2017). The maximum blend of ethanol is set at $15 \%$, however, $10 \%$ ethanol blend is still the most commonly available gasohol. The U.S. is projected to remain the leading producer of fuel ethanol, followed by Brazil.

The fuel ethanol production in Brazil equalled to 26,3 billion litres in 2014-2016 on average 
and it is forecasted to reach 32.5 billion litres in 2026. The fuel ethanol use in Brazil is assumed to be induced by a high mandatory blending rate $(27 \%)$ and applying a favourable tax rate to hydrous ethanol compared with gasohol (OECD/FAO, 2017). In the EU, the fuel ethanol production was 5.6 billion litres in 2014-2016 on average and it is projected to reach 5.8 billion litres by 2026. In the EU, the biofuels policy is regulated by the 2009 Renewable Energy Directive (RED) stating that renewable fuels should be raised to $10 \%$ of a total transport fuel consumption by 2020 on an energy equivalent basis, and by the Fuel Quality Directive (FQD), forcing fuel producers to cut the GHG intensity of transport fuels by $6 \%$ by 2020 . In 2015 , the "Indirect Land Use Changes" (ILUC) Directive introduced a 7\% limit on renewable energy in the transport sector coming from food crops. In February 2017, RED2 legislation was proposed, setting a limit of 3.8\% below the current 7\% gap in 2030 (EC, 2017).

A global biodiesel production is forecasted to rise from 33.8 billion litres in 2014-2016 on average to 40.5 billion litres by 2026 . The EU is the top biodiesel producer, with the production of 13.5 billion litres in 2014-2016 on average, representing $40 \%$ of a total output, followed by the U.S. and Brazil with 6.3 and 3.8 billion litres biodiesel output, respectively (Fig. 3). The EU will remain to be the major producer of biodiesel followed by the U.S., Brazil, Argentina, Indonesia and Thailand. In the EU, the biodiesel output is assumed to reach its maximum in 2020 with around 14.6 billion litres. For the U.S., the mandate for biodiesel is forecasted to uphold the 7.9 billion level specified for 2018 in the 2017 RFS rulemakings. Brazil is projected to remain the third largest biodiesel producer with 5.4 billion litres by 2026 (OECD/FAO, 2017)

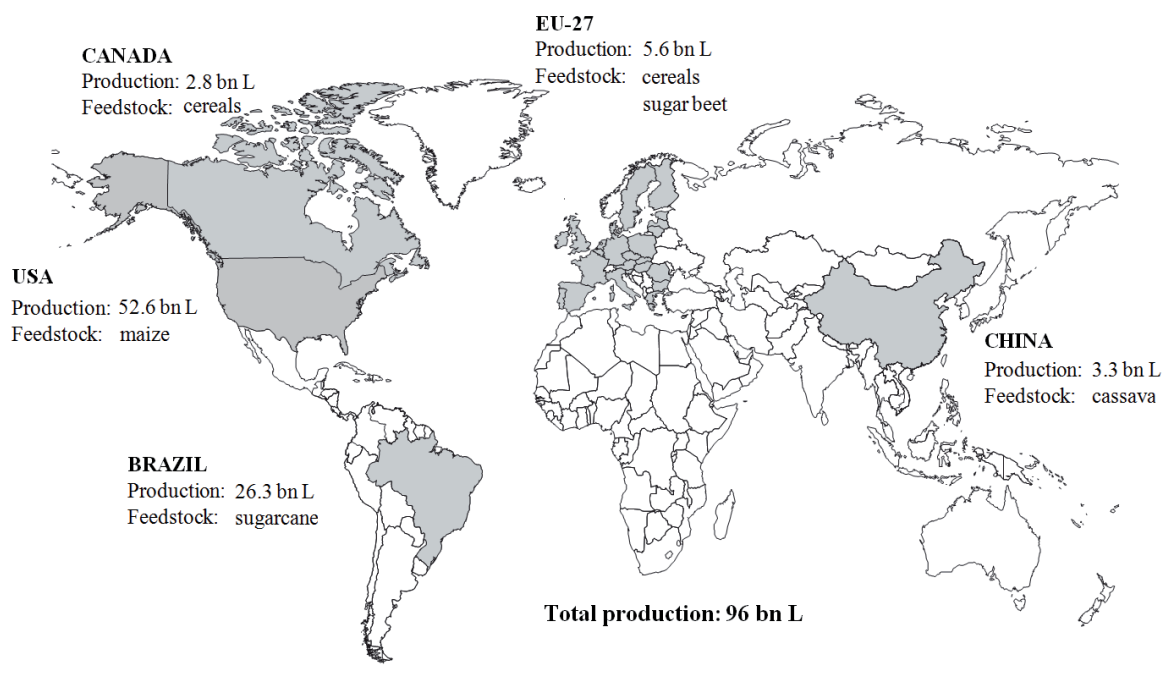

Fig. 2 - Word fuel ethanol production, average 2014-2016. Source: OECD/FAO (2017) 


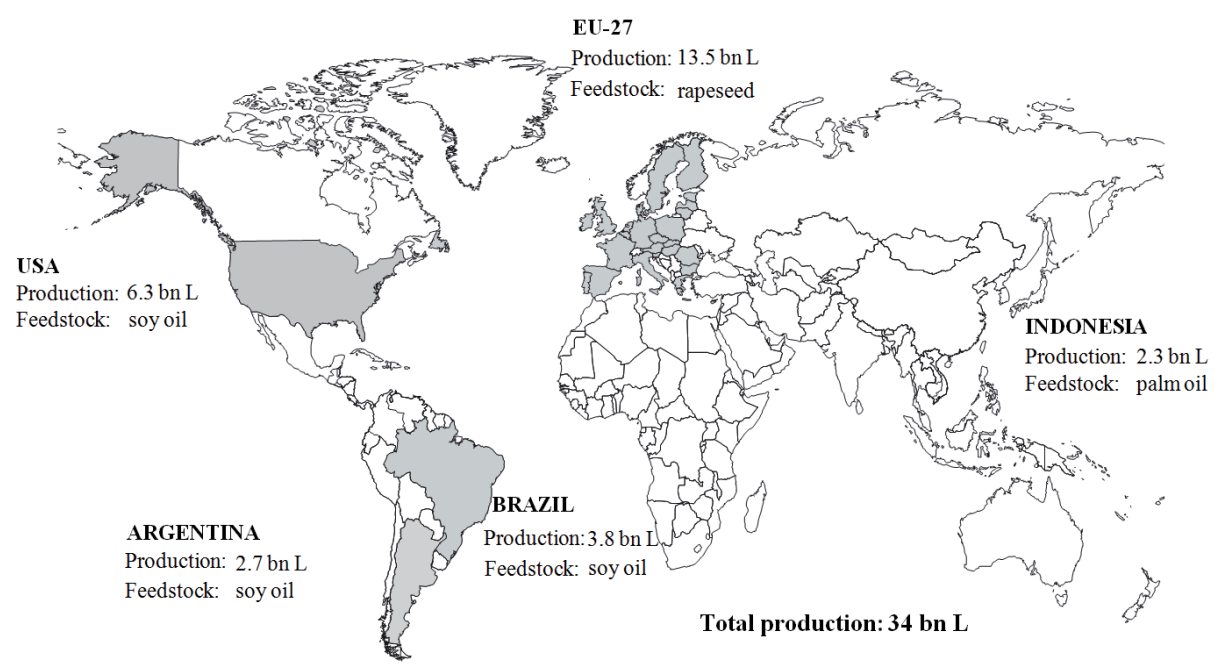

Fig. 3 - Word biodiesel production, average 2014-2016. Source: OECD/FAO (2017)

A diversion of food crops to biofuels feedstocks could increase food prices to the extent that net supply for food is inelastic. However, the global maize production has grown substantially over the period when the ethanol production has expanded, although not by as much as the total maize use. About 6-7\% of the global grain production, or 140 million tonnes of grain is used per annum by the bioethanol sector. However, $13 \%$ of world maize and $20 \%$ of world sugar cane consumption serves the fuel ethanol sector (OECD/FAO, 2017). Roughly $35 \%$ of the grain volume used for the purposes of the ethanol production is used by the livestock sector as a proteinrich animal feed component. Co-products regarded in this paper include DDGS (dried distillers' grains with solubles), soybean meal and rapeseed meal. Around $12 \%$ of the global vegetable oil - rapeseed, soybean and palm oil - production is used by the biodiesel industry, however, an increasing use of waste oil and tallow as feedstocks is expected in the EU and the U.S. About 20 million tonnes of vegetable oil is used per annum worldwide for the biodiesel production. Out of the 20 million tonnes rapeseed oil accounts for 9 million tonnes and soybean oil accounts for 7 million tonnes, representing about $70 \%$ of the total feedstocks used in the world biodiesel output (OECD/FAO, 2017).

The outline of the study is as follows: Section 1 presents an overview of recent evolution in the global biofuel market. Section 2 demonstrates results of the literature review related to the link between food and crude oil prices, and the role of a biofuel production in increased volatility in crude oil and food prices, and finally, the land use implications of a biofuel production. In Section 3, we describe the methodology used to analyse the link between food and crude oil prices, the impact of a biofuel production on an increased oil and food price volatility, and the land use implications of biofuel production. The results are summarised in Section 4, followed by discussion and conclusion. 


\section{LITERATURE REVIEWS}

Currently, about $2 \%$ of gross global area is used to produce feedstocks for biofuels. The energy price changes affect support for biofuels use in order to reduce dependence on crude oil imports. The increasing output of biofuels feedstocks is a significant driver of food commodity demand. However, lower energy prices reduce the production costs and prices of food commodities leading to relaxed policy pressures to boost biofuels production (World Bank, 2016a). Recent studies on the relationship between biofuels and food production have mainly concentrated on the U.S. and the EU, analysing the impacts of the use of grains and vegetable oil for biofuels production on global food prices (De Gorter \& Just, 2010). A biofuel production has started recently in many regions of the world and land acquisitions in Africa has also led to the production of biofuels but just few examples can be analysed (Locke \& Henley, 2013). Literature analysis exploring the impacts of biofuel projects on food security has limitations because projects have not been examined in equal detail (Barrett et al., 2012).

Biofuels policies led to a serious debate in 2007, when global grain prices reached an unprecedented level. The research of Dobbs, Oppenheim, and Thompson (2011) argued that we enter a new era of a higher commodity price volatility, which is now greater than at any time since the oil-shocked in 1970s. This argument did not prove correct because food price volatility is now back at pre-2007 levels although real prices remain somewhat higher. The factors leading to alltime high levels of food prices include a rapid economic growth in Asia (mainly in China), speculative influences on commodity futures prices and index-based investment activity (Gilbert \& Morgan, 2010). Abbott (2014) concludes that around one half of the rise in maize prices over the period of 2005-09 can be attributed to biofuels effects but that these impacts were dependent on food market factors which resulted in low stock levels. Instead, De Gorter, Drabik, and Just (2015) argue that the biofuel sector is responsible for almost $80 \%$ of the increase in feedstock prices. This is an enormous difference. On the contrary, others emphasize that the contribution of the biofuel production to the increased food prices is not significant (Durham, Davies, \& Bhattacharyya, 2012).

Several studies have estimated the transmission elasticity of energy to non-energy prices, including food prices in the range from 0.11 to 0.16 (Baffes, 2007; De Gorter et al., 2015; Gilbert, 1989). A rapid economic growth in emerging countries increases energy use and hence oil prices, and ultimately food prices (Gilbert, 2010). Another report (Baffes \& Dennis, 2013) concludes that increases in oil prices, changes in stocks and exchange rates, and not biofuel expansion were the reasons for agricultural commodity price increases since 2004 . It adds that $66 \%$ of price increases of biofuel feedstock commodities such as wheat and maize over the last decade were due to the oil price and the impact of biofuels, were negligible.

The more recent literature finds weak relationships between energy and non-energy crop prices (Reboredo, 2012; Saghaian, 2010; Zhang, Lohr, Escalante \& Wetzstein, 2010). Serra (2011) found a relatively close link between ethanol and sugarcane prices in Brazil. He added that crude oil and sugar-cane prices influence the ethanol prices. Gilbert (2010) observed correlation between the oil price and food prices as the result of common causation and not of a direct causal link. He added that the relationship between energy and food prices is also influenced by biofuels mandates. However, in case of a profitable biofuel production, the link between food and oil 
prices will be strengthened (Gilbert, 2010). Reboredo (2012) revealed no link between the prices of grain, soybeans and oil price fluctuations. Even different data frequencies (Zilberman, Hochman, Rajagopal, Sexton, \& Timilsina, 2013) or the national mandates of biofuels (De Gorter \& Just, 2010) may have an impact on the results. A recent study (World Bank, 2016b) highlights the main reasons for decreasing food prices after 2011. About one-third of the real price decline of maize, wheat, rice and soybean can be justified by the real oil price drop since fuel is a cost component of producing and transporting agricultural commodities. About one-sixth of the downturn in real grain prices can be described by a steady increase in incomes.

Nowadays, about 2\% (30-35 million gross hectares) of global cropland is used for biofuels feedstocks production. That is an increase of 25 million ha since 2000 (Langeveld, Dixon, van Keulen \& Quist-Wessel, 2014). In early biofuel impact assessments, the co-product output was not included and the land required for biofuels feedstock production was overestimated. However, a biofuel production is associated with animal feed production (OECD/FAO, 2017). Recent results on land use change GHG emissions demonstrate that Searchinger et al. (2008) over-estimated emissions significantly (Dunn, Mueller, Kwon, \& Wang, 2013). Credits for co-products include GHG emission and land use savings. Co-products of the biofuel industry are used in the feeding sector substituting for example maize and soymeal. The substitution of traditional animal feed with co-products reduces land use and hence GHG emission. Ethanol plants return around $35 \%$ of the grain used for processing back to the livestock sector, mainly in the form of DDGS. In a similar way, co-products of the biodiesel production are oil cakes substituting soybean as feed. By calculating co-products used as animal feed, the land needed for production of biofuel feedstocks declines from $2 \%$ to $1.5 \%$ of the global crop area (Popp et al., 2014).

\section{OBJECTIVES AND METHODOLOGY}

The aim of this study is to examine the cause of an increased food price volatility. We investigate whether the volatility in food prices is influenced by the transmission of crude oil prices or if it is the result of a growing biofuel output. The further aim of this research is to offer the outlook on the biofuel industry and the land use implications and GHG emission savings related to the production of co-products for animal feed.

One of the goal of our study is to check whether the link between crude oil and food prices is significant and constant over time? We expect to find a positive link between the crude oil prices and the price index of cereals, sugar and vegetable oil. In other words, we assume an increase in crude oil price to lead to an increase in cereals, sugar and vegetable oil prices. The study evaluates the link among the following variables: fuel prices (crude oil) and selected food prices (cereals, sugar and vegetable oil).

This paper provides a widespread survey of biofuels use. The survey benefits from a global perspective in contrast with the majority of the literature, which concentrates mainly on the United States. We use yearly data (2003 to 2016) for crude oil price, cereals, sugar and vegetable oil price index. Prices are given in USD per barrel of crude oil and price index of cereal, sugar and vegetable oil. The evolution of food, cereals, sugar and vegetable oil prices is represented by an index composed by the FAO. The crude oil price is expressed in USD and it is a simple average 
of three spot prices, namely the Dated Brent, West Texas Intermediate, and the Dubai Fateh. OECD Agriculture statistics (database) 2016 is the most comprehensive source of comparable statistics on global biofuel production and consumption.

This research demonstrates the fact that an increasing biofuel production has strengthened the link between food and oil prices, especially for those food products that are used for a biofuel production. Furthermore, an additional link can be recognised between food commodity and oil prices. The fluctuation of food prices can be justified mainly by transmission of oil price shocks. In addition, we demonstrate that the use of co-products as animal feed has land use implications including also GHG emission savings since they reduce land and the demand for chemical inputs required in the feed production.

\section{RESULTS}

A biofuel production was insignificant before 2000 and a sharp increase in food prices started around 2004. Since the 2000s, we have witnessed an enormous increase in a biofuel production and biofuels are believed to be, the driven force of a strong increase in food prices. Consequently, our investigated time span covers the period after 2003 and our analysis consists of data from 2003 to 2016. A biofuel production started approximately in 1990. First, it started with ethanol and then, biodiesel followed later. Cereals and sugarcane are the main crops used for the ethanol production, and a predominant feedstock for the biodiesel industry is vegetable oil. The ethanol production increased almost four-fold since 2003 reaching about 119 billion litres (out of this 96 billion litres of fuel ethanol) in 2016. For the same period, the biodiesel production rose eighteen-fold and achieved roughly 33 billion litres by 2016 (Fig. 4-5).

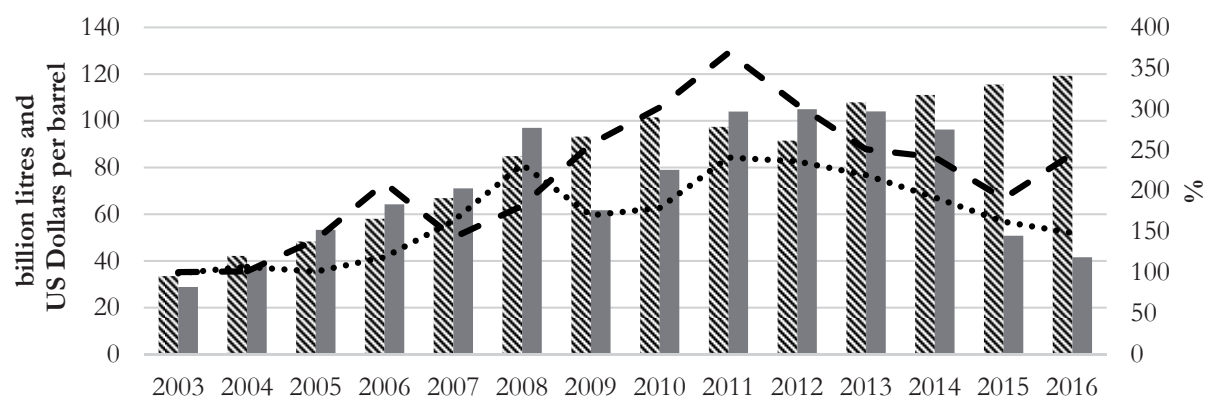

Num World ethanol production (billion litres)

Crude oil price, average (US Dollars per barrel)

-..... Cereals price index $(\%)$

- Sugar price index $(\%)$

Fig. 4 - Word ethanol production, crude oil price, cereals and sugar price index (2003-2016). Source: OECD/ FAO (2017b), FAO (2016), World Bank. (2016b) 
Cereals, sugar and vegetable oil prices were subject to price decreases between 2011-2015 but price increases started in 2004. Since 2006, food prices have fluctuated sharply and the price volatility increased. Selected feedstock prices co-moved with oil prices, however, sugar prices reached slower their equilibrium with crude oil prices than cereals and vegetable oil prices (Fig. 4-5). The results do not underline the assumption that the increasing output of biofuels has strengthened the relationship between prices of food commodities used for a biofuel production with crude oil. It can be stated that price links between food based feedstock and crude oil also exist without any biofuel impact (Fig. 6-7). Price changes in crude oil are triggering price changes in the final product regardless whether it is used for food or feedstock. With an increasing use of food crops for a biofuel production, they can be used interchangeably, particularly in transport fuels. Rising fuel prices make a biofuel production more attractive and the reverse happens with decreasing crude oil prices.

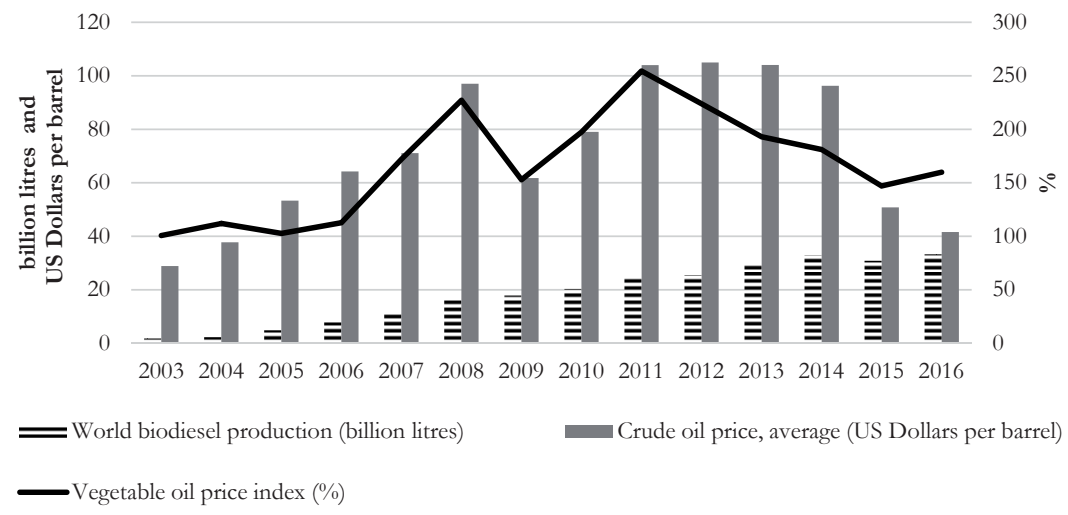

Fig. 5 - Word biodiesel production, crude oil price, vegetable oil price index (2003-2016). Source: OECD/FAO (2017b), FAO (2016), World Bank (2016b)

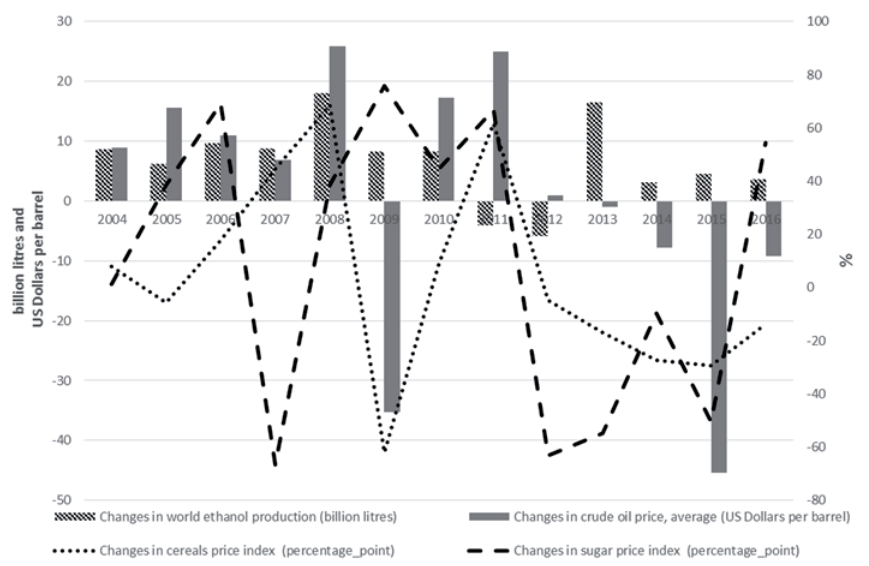

Fig. 6 - Changes in word ethanol production, crude oil price, cereals and sugar price index (2003-2016). Source: OECD/FAO (2017b), FAO (2016), World Bank (2016b) 


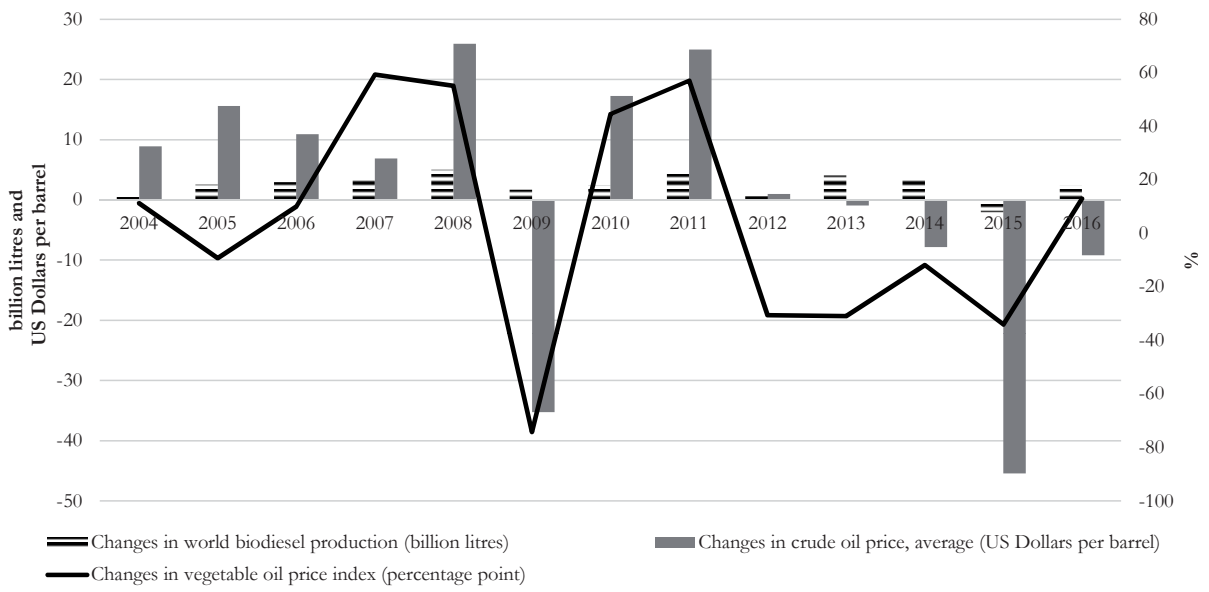

Fig. 7 - Changes in biodiesel production, crude oil price and vegetable oil price index (2003-2016). Source: OECD/FAO (2017b), FAO (2016), World Bank (2016b)

In another study, Balcombe and Rapsomanikis (2008) highlighted the close link between oil and sugar prices in Brazil, followed by adjusted sugar and ethanol prices after oil price impacts are nonlinear. Cereals and vegetable oil prices reach faster their equilibrium with oil prices than sugar prices in case of oil price fluctuations. Serra (2011) confirmed a close relationship between maize and energy prices, where a rising energy price leads to a higher maize price through the ethanol market. The analysis of Gilbert and Mugera (2014) reveals that the increasing biofuels output is partly responsible for the rising price volatility of food prices.

The co-product of a biofuel production is protein-rich animal feed. The output of the ethanol industry is about 45 million metric tonnes of animal feed. Distillers grains account for $90 \%$, the rest is gluten feed and gluten meal (RFA, 2017). The co-product of the biodiesel industry is oilseed meal, namely around 28 million tonnes of soybean meal and 13 million tonnes of rapeseed meal (RFA, 2017). The ethanol and biodiesel industry produces a total amount of animal feed equalling to $65-70$ million tonnes of soybean meal, or $30 \%$ of the soybean meal production worldwide in protein equivalent. The use of co-products as animal feed has land use implications including GHG emission savings. The share of land used for a feedstock production declines from around $2 \%$ to $1.5 \%$ of the world crop area.

\section{DISCUSSION}

A further research is needed to assess different impacts on food prices. Case studies provided different results on impacts of a biofuel production, however, more data for surveys could give us more detailed information on impacts of an increasing biofuel production emerging over time. The price volatility could be measured more correctly by use of higher-frequency data (monthly or daily data) and in the analysis of price co-movement biofuel food commodities (maize, sugar, rape, soybean, palm oil) and non-biofuel food commodities (wheat, rice), these 
should be included. Furthermore, a question arises whether the evolution of a biofuel production has been the consequence of support policies or whether profitability has given an incentive.

With the food versus fuel debate, studies focused on the relationship between oil and food prices. Even a strong relationship between crude oil and food prices does not prove the role of biofuel production in this link. An additional research is required to examine whether a biofuel production and consumption established a new relationship between food commodities and crude oil prices due to an increased use of food commodities as feedstock in a biofuel production.

Soybean meal is a primary source of proteins for the animal feed industry. Meeting an increasing consumption of animal proteins combined with reduction of the environmental impact is the main challenge. Soybean cultivation associated with deforestation has been under criticism for a long time. The substitution of soybean meal by protein-rich co-products of the biofuel industry implies that a sustainability gain is also ensured.

\section{CONCLUSION}

The results regarding an increasing food price volatility of different studies are hard to compare due to a wide range of focus and methodologies used in the studies. Declining energy prices have been accompanied by falling food prices after 2011. In addition, large investments during the 2000 s led to a robust supply response improving overall crop conditions. The energy content of agriculture is more or less the same as that of a remainder of the productive sector. This means that although there will be a transmission of oil price changes to nominal prices, however, this will not be true of deflated prices.

We found correlations between cereals, sugar and vegetable oil price index and crude oil prices from 2003 to 2016. Our results show that the main driver for food price fluctuation is mainly the oil price shock. Food prices have lately surged, decreased sharply and become more volatile. High fuel prices combined with a rising biofuel output created a relationship between crude oil and food prices. The extent of any relationship (pass-through) will depend on whether and how a biofuel production is constrained (biofuels mandate, limits on refining capacity, the blend wall). The real question, then, is how crude oil prices influence food prices and if this relationship (pass-through) will be constant over time. A further research, particularly between the price links of crude oil and more biofuel food products, is required to draw clear-cut conclusions. An increasing biofuel output has been associated with a rising protein-rich animal feed production. The use of co-products as animal feed has land use implications including GHG emission savings because co-products reduce land and the demand for chemical inputs required in the feed production. This way the share of land used for a feedstock production declines from around $2 \%$ to $1.5 \%$ of the world crop area.

\section{Acknowledgments}

Supported by the ÚNKP-17-4 New National Excellence Program of the Ministry of Human Capacities. 


\section{References}

1. Abbott, P. (2014). Biofuels, binding constraints, and agricultural commodity price volatility. In J.-P. Chavas, Hummels, D., \& Wright, B.D. (Ed.), The Economics of Food Price Volatility (pp. 440). Chicago: University of Chicago Press.

2. Baffes, J. (2007). Oil spills on other commodities. Resources Policy, 32 (3), 126-134.

3. Baffes, J., \& Dennis, A. (2013). Long-term drivers of food prices. World Bank Policy Research Working Paper (6455).

4. Balcombe, K., \& Rapsomanikis, G. (2008). Bayesian estimation and selection of nonlinear vector error correction models: the case of the sugar-ethanol-oil nexus in Brazil. American Journal of Agricultural Economics, 90 (3), 658-668.

5. Barrett, C. B., Bachke, M. E., Bellemare, M. F., Michelson, H. C., Narayanan, S., \& Walker, T. F. (2012). Smallholder participation in contract farming: comparative evidence from five countries. World Development, 40 (4), 715-730.

6. De Gorter, H., Drabik, D., \& Just, D. R. (2015). The economics of biofuel policies: impacts on price volatility in grain and oilseed markets. Springer.

7. De Gorter, H., \& Just, D. R. (2010). The social costs and benefits of biofuels: The intersection of environmental, energy and agricultural policy. Applied Economic Perspectives and Policy, 32 (1), 4-32.

8. Dobbs, R., Oppenheim, J., \& Thompson, F. (2011). A new era for commodities. McKinsey Quarterly, 4(1), 13-15.

9. Dunn, J. B., Mueller, S., Kwon, H.-y., \& Wang, M. Q. (2013). Land-use change and greenhouse gas emissions from corn and cellulosic ethanol. Biotechnology for biofuels, 6 (1). https:// dx.doi.org/10.1186/1754-6834-6-51.

10. Durham, C., Davies, G., \& Bhattacharyya, T. (2012). Can biofuels policy work for food security. An analytical paper for discussion. UK Department for Environment, Food and Rural Affairs (DEFRA): Devon, UK., 1-29.

11. EC (2017). European Commission. Proposal for a Directive of the European Parlament and of the Council on the promotion of the use of energy from renewable sources, This document corrects document COM (2016) 767 final of 30.11.2016, http://eur-lex.europa.eu/legal-content/ EN/TXT/?uri=CELEX:52016PC0767R\%2801\%29.

12. EPA (2017). Renewable Fuel Standard Program, Renewable Fuel Standard Program: Standards for 2017 and Biomass-Based Diesel Volume for 2018. United States Environmental Protection Agency, Retrieved from https://www.epa.gov/renewable-fuel-standard-program/final-renewablefuel-standards-2017-and-biomass-based-diesel-volume.

13. FAO (2016). Food price index. http://www.fao.org/worldfoodsituation/foodpricesindex/en/.

14. Gilbert, C. L. (1989). The impact of exchange rates and developing country debt on commodity prices. Economic Journal, 99 (397), 773-783.

15. Gilbert, C. L. (2010). How to understand high food prices. Journal of Agricultural Economics, $61(2), 398-425$. 
16. Gilbert, C. L., \& Morgan, C. W. (2010). Food price volatility. Philosophical Transactions of the Royal Society B: Biological Sciences, 365 (1554), 3023-3034.

17. Gilbert, C. L., \& Mugera, H. K. (2014). Food commodity prices volatility: The role of biofuels. Natural Resources, 2014 (5), 200-212. http://dx.doi.org/10.4236/nr.2014.55019.

18. IEA (2016). Key world energy statistics. International Energy Agency

19. Langeveld, J. W., Dixon, J., van Keulen, H., \& Quist-Wessel, P. (2014). Analyzing the effect of biofuel expansion on land use in major producing countries: evidence of increased multiple cropping. Biofuels, Bioproducts and Biorefining, 8 (1), 49-58. http://dx.doi.org/10.1002/ bbb.1432.

20. Locke, A., \& Henley, G. (2013). Scoping report on biofuels projects in five developing countries. Retrieved from London: https://www.odi.org/sites/odi.org.uk/files/odi-assets/ publications-opinion-files/8394.pdf.

21. OECD/FAO (2017). OECD-FAO Agricultural Outlook 2017-2026. OECD Publishing. Paris.

22. Popp, J., Lakner, Z., Harangi-Rakos, M., \& Fári, M. (2014). The effect of bioenergy expansion: food, energy, and environment. Renewable and Sustainable Energy Reviews, 32, 559578. http://dx.doi.org/10.1016/j.rser.2014.01.056.

23. Reboredo, J. C. (2012). Do food and oil prices co-move? Energy Policy, 49, 456-467.

24. RFA (2017). World fuel ethanol production. Renewable Fuels Association: http://www. ethanolrfa.org/resources/industry/statistics/\#1454099103927-61e598f7-7643.

25. Saghaian, S. H. (2010). The impact of the oil sector on commodity prices: Correlation or causation? Journal of Agricultural and Applied Economics, 42 (3), 477-485.

26. Searchinger, T., Heimlich, R., Houghton, R. A., Dong, F., Elobeid, A., Fabiosa, J., \& Yu, T.-H. (2008). Use of US croplands for biofuels increases greenhouse gases through emissions from land-use change. Science, 319 (5867), 1238-1240. http://dx.doi.org//10.1126/ science.1151861.

27. Serra, T. (2011). Volatility spillovers between food and energy markets: a semiparametric approach. Energy Economics, 33 (6), 1155-1164.

28. World Bank (2016a). Special Focus: From energy prices to food prices: Moving in tandem? Commodity Markets Outlook, July 2016. 10: http://pubdocs.worldbank.org/en/642011469546341568/ CMO-July-2016-Special-Focus.pdf.

29. World Bank (2016b). Energy production and consumption statistics. Retrieved from http://www. indexmundi.com/Commodities/?commodity $=$ crude-oil\&months $=180$

30. Zhang, Z., Lohr, L., Escalante, C., \& Wetzstein, M. (2010). Food versus fuel: What do prices tell us? Energy Policy, 38 (1), 445-451.

31. Zilberman, D., Hochman, G., Rajagopal, D., Sexton, S., \& Timilsina, G. (2013). The impact of biofuels on commodity food prices: Assessment of findings. American Journal of Agricultural Economics, 95(2), 275-281. https://doi.org/10.1093/ajae/aas037. 


\section{Contact information}

Oláh Judit, Ph.D.

University of Debrecen, Faculty of Economics and Business 4032 Debrecen, Hungary

Email:olah.judit@econ.unideb.bu

Lengyel Péter, Ph.D.

University of Debrecen, Faculty of Economics and Business 4032 Debrecen, Hungary

Email:lengyel.peter@econ.unideb.bu

Balog Péter, Ph.D.

University of Debrecen, Faculty of Economics and Business 4032 Debrecen, Hungary

Email:balogh.peter@econ.unideb.hu

Harangi-Rákos Mónika, Ph.D.

University of Debrecen, Faculty of Economics and Business 4032 Debrecen, Hungary

Email:rakos.monika@econ.unideb.bu

Popp József, DSc

University of Debrecen, Faculty of Economics and Business 4032 Debrecen, Hungary

Email:popp.jozsef@econ.unideb.bu 